\title{
HUBUNGAN ANTARA GRATITUDE DENGAN PSYCHOLOGICAL WELL- BEING IBU YANG MEMILIKI ANAK TUNAGRAHITA DI SLB NEGERI SALATIGA
}

\author{
Theresia Lisiau Ratnayanti \\ Theresianana95@gmail.com \\ Fakultas Psikologi - Universitas Kristen Satya Wacana \\ Enjang Wahyuningrum \\ ewahyuningrum@gmail.com \\ Fakultas Psikologi - Universitas Kristen Satya Wacana
}

\begin{abstract}
ABSTRAK
Penelitian ini bertujuan untuk mengetahui hubungan antara gratitude dengan psychological well-being pada ibu yang memiliki anak tunagrahita. Dalam penelitian ini, pengambilan data menggunakan metode kuantitatif dengan teknik korelasi Product Moment dari Carl Pearson. Hipotesis pada penelitian ini adalah terdapat hubungan positif antara gratitude dengan psychological well-being pada ibu yang memiliki anak tunagrahita. Skala pertama yang digunakan adalah Ryff's psychological well-being scale yang terdiri dari 42 item dengan reliabilitas $(\alpha) 0,848$. Skala kedua yang digunakan adalah The Gratitude Questionnaire-Six Item Form (GQ-6) yang memiliki 6 item dengan reliabilitas $(\alpha) 0,82$. Sampel dalam penelitian ini adalah 51 ibu yang memiliki anak tunagrahita yang bersekolah di SLB Negeri Salatiga. Hasil penelitian ini menunjukkan bahwa terdapat hubungan positif yang signifikan antara gratitude dan psychological well-being dengan hasil $\mathrm{r}=0.322$ dengan nilai signifikansi sebesar $0,011(\mathrm{p}<0,05)$ yang artinya semakin tinggi gratitude maka semakin tinggi pula psychological well-being, begitu sebaliknya. Hasil penelitian menunjukkan bahwa gratitude memberikan sumbangan sebesar 10,37\%. Hal ini dapat menunjukkan bahwa 89,63\% PWB ibu yang memiliki anak tunagrahita masih dipengaruhi oleh faktor lain.
\end{abstract}

Kata Kunci: Psychological Well-being, Gratitude, Tunagrahita

\section{PENDAHULUAN}

Kehadiran anak dalam kehidupan berkeluarga adalah harapan dan kebahagiaan setiap pasangan suami istri. Setiap keluarga tentu berharapuntukmemilikianakyangmenyenangkan, sehat dan pintar yang nantinya akan menjadi penerus dalam keluarga. Namun tidak semua harapan orang tua ini dapat terwujud, beberapa orang tua justru dikarunia anak dengan kekhususan yang berbeda dari anak pada umumnya. Kekhususan yang dimaksud adalah seperti anak yang mengalami keterbelakangan mental, salah satunya adalah tunagrahita. Untuk mendiagnosis apakah anak tergolong tunagrahita atau tidak, dapat dilihat dari kemampuan intelektual dan perilakunya dalam beradaptasi seperti kemampuan dalam menghadapi kehidupan sehari-hari, contohnya ketrampilan untuk berpakaian (Suharmini, 2009). Ketika orangtua mengetahui bahwa mereka memiliki anak berkebutuhan khusus, harapan-harapan yang selama ini didambakan oleh orang tua tentu seketika berubah menjadi kekecewaan. Menurut 
hasil penelitian yang dilakukan oleh Kumar (2008) orang tua yang memiliki anak tunagrahita dipastikan lebih mudah mengalami stres psikologis dibandingkan dengan orang tua dari anak yang normal. Stres diakibatkan karena tua dari anak tunagrahita baik beban secara fisik, psikis dan sosial. Terutama seorang ibu yang pada umumnya lebih banyak berhubungan dengan merawat dan membesarkan anak.

Dari hasil wawancara, masih ada ibu yang kurang dapat menerima kenyataan bahwa keadaan anaknya berbeda dari kebanyakan anak pada umumnya, hal ini dirasakan terutama di awal ketika ibu menyadari bahwa anaknya merupakan penyandang tunagrahita. Pada saat ibu mengetahui bahwa anaknya adalah penyandang tunagrahita ibu merasa sedih dan kecewa dengan keadaan yang menimpa dirinya, mengeluh dan marah kepada Tuhan mengapa harus dirinya yang dikarunia anak tunagrahita. Dalam mendampingi dan membimbing, ibu juga menjadi mudah menyerah, selain itu ada pula ibu yang merasa malu ketika orang lain membahas tentang anak dan hal ini membuat beberapa ibu menyerahkan anak kepada pengasuh. Kondisi ketika ibu merasa malu untuk membahas anaknya yang tunagrahita kepada orang lain, membuat hubungan ibu dan tetangga atau lingkungan sekitar sempat renggang. Hal lain yang ditunjukkan adalah dengan perilaku ibu seperti terlalu mengasihani anak dan membatasi pergaulan anak. Selain kurang dapat menerima keadaannya, ada pula ibu yang hanya berpikir bahwa untuk saat ini yang bisa ia lakukan hanya merawat anaknya dan tidak tahu tujuan kedepannya akan berbuat apa. Kondisi dan perasaan-perasaan seperti itu membuat beberapa ibu merasa stres karena terus memikirkannya. Namun, ada pula ibu yang berkeyakinan bahwa jalan hidupnya dan anaknya masih panjang, tidak perlu berlarut-larut sedih dan kecewa terhadap keadaan karena mau tidak mau harus dapat menjalani dan me- nyesuaikan diri. Dengan memiliki anak tunagrahita ada ibu yang merasa masih dapat melakukan banyak hal lainnya yang bermanfaat bagi diri dan orang disekitarnya, ibu berpikir bahwa yang terpenting ibu harus memberikan stimulus kepada anak sehingga sebisa mungkin anak dapat melayani diri sendiri seperti mandi, menggunakan pakaian, dan masih banyak lainnya. Dari hasil wawancara, ada ibu yang ternyata memiliki permasalahan dalam kesejahteraan psikologis seperti belum dapat menerima keadaan yang menimpa dirinya, ada yang tidak memiliki tujuan hidup kedepan karena yang dianggap penting hanya bagaimana merawat anak dengan baik dan sempat memiliki hubungan yang kurang baik dengan orang-orang di lingkungan sekitarnya karena enggan bercerita tentang anak dan cenderung membatasi pergaulan anak.

Masing-masing individu tentu berusaha untuk mencapai kesejahteraan dalam hidupnya termasuk ibu dari anak tunagrahita. Psychological well-being (PWB) menurut Ryff(1989) merupakan realisasi dari pencapaian penuh potensi individu dimana individu dapat menerima segala kekurangan dan kelebihan dirinya, mandiri, mampu membina hubungan yang positif dengan orang lain, dapatmenguasai lingkungannya dalam arti mampu memodifikasi lingkungan agar sesuai dengan keinginannya, memiliki tujuan hidup, serta terus mengembangkan pribadinya. Keenam hal ini menjadi aspek dari PWB dan faktor-faktor yangmemengaruhi PWB seseorang menurut Ryff(1995) adalah usia, jenis kelamin, budaya, dan status sosial ekonomi.

Ryff(1989) mengatakan bahwa evaluasi terhadap pengalaman dapat menyebabkan seseorang menjadi pasrah terhadap keadaan yang membuat PWB-nya rendah, atau berusaha memperbaiki keadaan hidupnya yang akan membuat PWB meningkat. Orangyang memiliki skor PWB rendah akan mengalami kesulitan 
dalam mengatur urusan sehari-hari, merasa tidak mampu untuk mengubah atau meningkatkan kualitas lingkungan sekitarnya, dan kurang memiliki kontrol terhadap lingkungan.

Diener, dkk (dalam Harimukthi \& Dewi, 2014) menyatakan bahwa kesejahteraan psikologis merupakan suatu yang penting karena memiliki kesejahteraan psikologis yang tinggi akan mendukung kesehatan yang lebih baik, memperpanjang umur, meningkatkan usia harapan hidup, dan menggambarkan kualitas hidup dan fungsi individu. Bagi ibu yang memiliki anak tunagrahita, tentumenginginkan PWByang tinggi bila dampak yang didapatkan begitu positif bagi dirinya. Ziskis (2010) melakukan penelitian dan menemukan bahwa gratitudemerupakan variabel mediator antara kepribadian dengan PWB. Selain itu, menurut penelitian Wood, Joseph dan Maltby (2009) menunjukkan bahwa rasa syukur memiliki hubungan yang positif dengan beberapa aspek PWB yaitu pertumbuhan pribadi, hubungan positif dengan orang lain, tujuan hidup dan penerimaan diri namun syukur tidak begitu memiliki hubungan yang besar pada dua aspek PWB lainnya yaitu otonomi dan penguasaan lingkungan. Menurut Haworth (1997) kesejahteraan yang ingin masing-masing individu capai dapat ditingkatkan melalui pengungkapan rasa syukur.

Menurut Emmons dan Stern (2013) syukur adalah perasaan yang terjadi di antar pribadi ketika seseorang mengakui bahwa dirinya menerima manfaat yang berharga dari yang lain. Rasa syukur adalah sesuatu yang penting jika bukan hanya menjadi alat untuk perbaikan diri. Tujuan utamanya adalah untuk merefleksikan kembali kebaikan yang telah diterima. Emmons dan McCullough (2003) mencatat bahwa syukur memiliki komponen kognitif dan afektifyang biasanya terkait dengan persepsi bahwa seseorang telah menerima keuntungan pribadi yang tidak sengaja dicari dan pantas yang diperoleh melalui niat baik dari orang lain. Menurut McCullough, Emmons dan Tsang (2002) ada empat kualitas rasa syukur yaitu intensitas (intensity) merupakan perasaan intens akibat emosi positif dari rasa syukur. Frekuensi (frequency) seberapa sering seseorang bersyukur. Selanjutnya rentang waktu (span) yang merujuk pada sejumlah kondisi kehidupan dimana seseorang merasa bersyukur setiap waktunya, dan yang terakhir adalah kepadatan (density) yang menunjukkan seberapa banyak hal-hal yang disyukuri dan kepada siapa saja rasa syukur tersebut dilimpahkan.

Daripenelitian sebelumnyayang dilakukan oleh Wood, Joseph dan Maltby (2009) menunjukkan bahwa gratitude menjadi penting untuk kesejahteraan psikologis. Selain itu, penelitian yang dilakukan Fitria (2012) menunjukkan bahwa terdapat hubungan positif yang signifikan antara gratitude dan PWB pada mahasiswa. Ada pula penelitian yang dilakukan oleh Debby (2016) yang menunjukkan bahwa terdapat hubungan yang positif dan signifikan antara gratitude dan PWB pada mahasiswa UKSW yang kuliah sambil bekerja full time. Dalam penelitian sebelumya, subjek yang lebih banyak diambil adalah kalangan remaja, maka peneliti ingin lebihmemfokuskan subjek penelitian pada orang tua khususnya ibu sehingga penelitian ini akan meneliti mengenai hubungan antara gratitude dan PWB pada ibu yang memiliki anak tunagrahita.

\section{METODE PENELITIAN}

Jenis penelitian yang digunakan dalam penelitian ini adalah jenis penelitian kuantitatif korelasional. Menurut Azwar (2010) dengan metode kuantitatif akan diperoleh signifikansi perbedaan kelompok atau signifikansi hubungan antar variable yang diteliti. Penelitian kuantitatif juga menekankan analisisnya pada data-data numerical (angka) yang diolah dengan metode 
statistika. Variabel- variabel yang akan dilibatkan dalam penelitian ini adalah variabel bebas $(\mathrm{X})$ yaitu Gratitude dan variabel tergantung $(\mathrm{Y})$ yaitu Psychological Well-Being. Populasi dalam penelitian ini adalah semua ibuyangmemilikianak tunagrahita yang bersekolah di SLB Negeri Salatiga. Penelitian ini menggunakan $51 \mathrm{ibu}$ dengan teknik pengambilan sampel Purposive Sampling. Pengambilan sampel dilakukan dengan berdasarkan pada kriteria-kriteria tertentu (Sugiyono, 2011). Adapun kriterianya antara lain: 1) Merupakan ibu kandung yang tinggal bersama dengan anak, 2) Memiliki anak satu atau lebih yang menyandang tunagrahita, 3) Anak merupakan siswa yang bersekolah di SLB N Salatiga.

Alat ukur yang digunakan adalah The Gratitude Questionnaire-Six Item Form (GQ-6). Skala pengukuran gratitude ini disusun oleh McCullough dan Emmons (2002) dimana skala ini terdiri dari 6 item pernyataan yaitu 4 item favorable dan 2 item unfavorable. Pengukuran inimemiliki 7 pilihan alternatifrespon yaitu dari sangat setuju sampai sangat tidak setuju dengan masing-masing pilihan respon memiliki skor. Dalam penelitian ini reliabilitas dari skala gratitude mengacu pada penelitian McCullough, Emmons \& Tsang (dalam Froh, dkk, 2011) yang menghasilkan reliabilitas sebesar $(\alpha) 0,82$. Oleh karena reliabilitas skala gratitude sudah baik maka dalam penelitian ini peneliti tidak menguji kembali reliabilitas skala gratitude. Alat ukur yang digunakan selanjutnya adalah Ryff's Psychological Well Being Scales. Skala pengukuran PWB ini diciptakan oleh Ryff(1989) dan menjabarkan enam aspek PWB. Skala ini dimodifikasi dan disesuaikan dengan partisipan penelitian dimana terdiri dari 42 item pernyataan yang dibagi dalam 7 item untuk masing-masing aspek. Pengukuran ini memiliki 6 pilihan alternatif respon yaitu dari sangat setuju sampai sangat tidak setuju dengan masing-masing pilihan respon memiliki skor. Pengujian reabilitas dan seleksi item (daya diskriminasi) pada penelitian ini menggunakan data try out terpakai. Penentuan item-item yang memiliki daya diskriminasi menggunakan ketentuan dariAzwar(2010) yang menyatakan bahwa item pada skala pengukuran dapat dikatakan valid apabila $\geq 0,25$. Daya diskriminasi item dari $0.273-0.551$ dan diperoleh 26 item dengan reliabilitas $(\alpha)$ sebesar 0,848 . Teknik analisis data (uji diskriminasi) menggunakan teknik korelasi Pearson Product Moment dengan menggunakan bantuan program SPSS 18.0 for windows. Reliabilitas menggunakan Cronbach's Alpha, seleksi aitem menggunakan Item-total Statistic, uji normalitas menggunakan One-Sample KolmogorovSmirnov Test, uji linieritas menggunakan ANOVA, uji korelasi menggunakan Correlations.

\section{HASIL PENELITIAN}

Berdasarkan hasil analisis deskriptif diperoleh data minimum pada variabel gratitude sebesar 16 dan data maksimum sebesar 42 dengan mean 36 dan standar deviasi 3,96. Untuk variabel PWB, data minimum sebesar 96 dan data maksimum sebesar 148 dengan mean 122,71 dan standar deviasi 11,59. Untuk variabel gratitude memiliki total 6 item dengan 7 alternatif respon dan skor yang bergerak dari 1-7. Untuk variabel PWB memiliki total 26 item dengan 6 alternatif respon dan skor yang bergerak dari 1-6. Adapun total skor terendah untuk gratitude adalah 6 dan tertinggi adalah 42 serta untuk PWB skor terendah adalah 26 dan tertinggi 156. Interval skor untuk setiap kategori ditentukan dengan menggunakan rumus interval dalam Hadi (2000).

Dalam kategori skor skala gratitude, dapat diketahui bahwa terdapat 40 orang $(78 \%)$ yang memiliki gratitude sangat tinggi, 10 orang (20\%) berada pada kategori tinggi dan 1 orang (2\%) berada pada kategori rendah. Sedangkan 
dalam kategori skor skala PWB dapat diketahui bahwa terdapat 12 orang $(23,53 \%)$ yang memiliki PWB sangat tinggi, 36 orang $(70,58 \%)$ berada pada kategori tinggi dan 3 orang $(5,89 \%)$ berada pada kategori sedang.

Uji Normalitas menggunakan uji Kolmogorov-Smirnov yang menunjukkan skala PWB (K-S-Z $=0,457, p=0,985, p>0,05)$ dan skala gratitude $(\mathrm{K}-\mathrm{S}-\mathrm{Z}=1,319, p=0,062$, $p>0,05)$. Dapat disimpulkan bahwa variabel gratitude dan PWB memiliki sebaran data yang berdistribusi normal.

Uji linieritas menggunakan uji ANOVA yang menunjukan data gratitude dan PWB dengan F linearity sebesar 6,390 dan nilai signifikansi sebesar 0,016 ( $\mathrm{p}<0,05)$, F deviation from linearity sebesar 1,535 dan nilai signifikansi sebesar 0,156 ( $\mathrm{p}>0,05)$ maka hal ini dapat disimpulkan bahwa variabel gratitude dan PWB bersifat linier.

Berdasarkan uji asumsi yang telah dilakukan sebelumnya dapat diketahui bahwa data berdistribusi normal dengan nilai $\operatorname{sig}(\mathrm{p}>$ $0,05)$ dan kedua variabel penelitian linier $(p>$ 0,05), maka uji korelasi yang dilakukan menggunakan Pearson Correlation Product Moment. Berdasarkan hasil uji korelasi antara kedua variabel dapat disimpulkan bahwa terdapat hubungan positifyang signifikan antara kedua variabel yang dapat diartikan semakin tinggi pada ibu yang memiliki anak tunagrahita begitupula sebaliknya semakin rendah gratitude maka semakin rendah PWB. Ditemukan pula bahwa gratitude memberikan sumbangan sebesar 10,37\% artinya $89,63 \%$ PWB ibu yang memiliki anak tunagrahita masih dipengaruhi oleh faktor-faktor lain.

\section{PEMBAHASAN}

Hasil uji korelasi menunjukkan adanya korelasi positifyang signifikan antara gratitude dan PWB ibu yang memiliki anak tunagrahita di mana $r=0,322$ dan $r^{2}=0,10368$ dengan nilai signifikansi $0,011(p<0,05)$. Hasil ini menunjukkan bahwa semakin tinggi gratitude maka semakin tinggi PWB pada ibu yang memiliki anak tunagrahita dan semakin rendah gratitude maka semakin rendah pula PWB pada ibu yang memiliki anak tunagrahita. Berdasarkan hasil analisis deskriptif, data menunjukkan bahwa rata-rata partisipan penelitian memiliki gratitude dalam kategori sangat tinggi dan PWB dalam kategori tinggi.

Penelitian ini sesuai dengan penelitian sebelumnya yang menunjukkan bahwa gratitude menjadi penting untuk kesejahteraan psikologis dalam kaitannya dengan kepribadian (Wood, Joseph \& Maltby 2009). Sesuai pula dengan penelitian yang dilakukan oleh Fitria (2012) dimana penelitiannya menunjukkan bahwa terdapat hubungan positifyang signifikan antara gratitude dan PWB pada mahasiswa yang juga ditemukan bahwa gratitude memberikan sumbangan sebesar 28,73\% untuk PWB pada mahasiswa. Sama halnya dengan penelitian yang dilakukan Debby (2016) yang menunjukkan bahwa terdapat hubungan yang positif dan signifikan antara gratitude dan PWB pada mahasiswa UKSW yang kuliah sambil bekerja full time. Dari hasil penelitian tersebut dapat diartikan walaupun dengan partisipan penelitian yang berbeda namun tetap menunjukkan adanya hubungan positifyang signifikan antara gratitude dan PWB.

Seseorang yang mensyukuri kehidupannya dapat mengakui dan menerima berbagai aspek dalam diri termasuk kualitas yang baik dan buruk serta merasa positif tentang kehidupan masa lalu. Menurut Watkins dkk (2003) gratitude menjadi kekuatan yang paling penting untuk mencapai kehidupan yang lebih baik sehingga memiliki maksud dan tujuan dalam hidup juga tidak terlepas dari adanya rasa bersyukur untuk kehidupan yang sedang dijalani. 
Menurut Park, Peterson, dan Seligman (2004) salah satu kekuatan diri yang positif yang memberikan keuntungan bagi diri individu adalah gratitude. Dengan adanya rasa syukur mampu membantu meningkatkan pertumbuhan pribadi. Seseorang dengan PWB tinggi memiliki perasaan bahwa diri itu tumbuh dan berkembang, terbuka untuk pengalaman baru, menyadari potensi pada dirinya, melakukan perbaikan dalam diri dan perilaku dari waktu ke waktu. Menurut Watkins dkk (2003) individu yang bersyukur akan menghargai setiap kontribusi yang diberikan orang lain, dengan begitu relasi dengan orang lainpun dapat berlangsung dengan baik karena seseorang dengan PWB tinggi memiliki rasa hangat dengan orang lain, mempercayai hubungan dengan oranglain, memiliki empatiyang kuat, mampu memahami pemberian dan penerimaan dalam suatu hubungan.

Dari data yang dihasilkan PWB, rata-rata partisipan penelitian mendapatkan hasil pada kategori tinggi, dari hasil wawancara pada tanggal 5-7 September 2016 yang sudah dilakukan dengan beberapa ibu yang memiliki anak tunagrahita, pada mulanya ibu merasa sedih, kecewa, malu, bahkan ada yang mengatakan bahwa dirinya tidak terima dengan apa yang menimpa dirinya. Anak dianggap sebagai beban dalam hidup, namun seiring berjalan waktu ibu yang memiliki anak tunagrahita ini mulai berpikir bahwa tanpa bantuan mereka, anak tidak dapat melakukan banyak hal dalam kehidupannya sehingga secara bertahap mereka mulai menyadari bahwa anak yang mereka miliki bukan merupakan aib dan beban bagi mereka. Hasil yang didapat dari PWB bisa dalam kategori yang tinggi, hal ini diperkuat karena kebanyakan ibu yang peneliti temui sudah dalam kondisi dimana mereka dapat menyadari bahwa anak adalah anugerah yang sudah sepantasnya diterima. Banyak diantaranya yang memiliki tujuan hidup kedepan untuk menjadi pribadi yang lebih baik salah satunya dengan tidak keberatan untukmeningkatkan keterampilan atau pengetahuan mereka, ibuyang peneliti temui juga rata-rata dapat bersosialisasi dengan cukup baik terlebih dengan orangtua lain yang memiliki anak tunagrahita pula yang dianggap senasib dengannya. Beberapa kondisi yang ditemukan dapat menunjukkan bahwa ibu memiliki PWB yang baik karena menurut Ryff(1989) ciri-ciri orang yang memiliki kesejahteraan psikologis yang tinggi adalahmandiri, memiliki kemampuan penyesuaian diri dengan lingkungan sekitarnya, keinginan untuk terus tumbuh dan berkembang dalam segala hal, hubungan yang hangat dengan orang lain, memiliki tujuan tertentu yang ingin dicapai dalam hidup, dan penilaian positif terhadap dirinya sendiri.

Dari hasil wawancara banyak pula ibu yang berpendapat bahwa bersyukur adalah suatu hal yang sangat penting saat ini, dengan melihat beberapa teman dengan anak tunagrahita yang membutuhkan perhatian lebih besar, ibuibu ini dapat mensyukuri kehadiran anak yang beberapa diantaranya masih dapat berjalan sendiri, masih dapat berbicara dengan jelas, merawat diri sendiri dan masih banyak hal yang dapat membuat ibu merasa bersyukur. Ketika ibu tidak atau kurang bersyukur, mereka merasa seperti mudah menyerah dalam membesarkan anak, iri kepada teman yang memiliki anak normal dan menjadi mudah tersinggung serta stress. Hasil wawancara ini sesuai dengan penelitian yang dilakukan McCullough, Emmons, dan Tsang (2002) yang menunjukkan bahwa orang yang memiliki rasa syukur yang tinggi ternyata memiliki rasa iri hati dan depresi yang rendah. Rasa bersyukur menurut ibu juga membuat dirinya semakin tenang, sabar, dan memiliki perasaan yang lebih damai sehingga merasa lebih baik dalam menjalani kehidupan. Hal tersebut diperkuat oleh penelitian Wood, Joseph, dan Maltby (2009) yang mengatakan 
bahwa rasa syukur menjadi salah satu kekuatan positifyang paling memberikan keuntungan bagi individu dan bahwa gratitude merupakan satu hal yang dapat memengaruhi PWB.

\section{SIMPULAN}

Dari hasil penelitian, dapat disimpulkan bahwa terdapat hubungan positif yang signifikan antara gratitude dan PWB ibu yang memiliki anak tunagrahita di SLB Negeri Salatiga. Sebagian partisipan (78\%) memiliki gratitude pada kategori sangat tinggi dan PWB pada kategori (70,58\%) berada pada kategori tinggi. Dalam penelitian juga ditemukan bahwa gratitude memberikan sumbangan sebesar $10,37 \%$ yang artinya $89,63 \%$ PWB ibu yang memiliki anak tunagrahita masih dipengaruhi oleh faktor-faktor lain seperti religiusitas, dukungan sosial, kecerdasan emosi dan masih banyak faktor lainnya.

\section{DAFTAR PUSTAKA}

Azwar, S. 2004. Metode Penelitian. Yogyakarta: Pustaka Pelajar.

. 2010. Metode Penelitian. Yogyakarta: Pustaka Pelajar.

Chintya, D. 2016. Hubungan antara gratitude dengan psychological well-being pada mahasiswa UKSWyang kuliah sambil bekerja full time. Skripsi tidak diterbitkan. Salatiga: Fakultas Psikologi Universitas Kristen Satya Wacana.

Emmons, A. R.,\& Stern, R. 2013. Gratitude as a psychotherapeutic intervention. Journal of Clinical Psychology: In Session, 69, 846-855.

Froh, J. J., Fan, J., Emmons, A. R., Bono, G., Huebner, S. E., \& Watkins, P. (2011). Measuring gratitude in youth: assessing the psychometric properties of adult gratitude scales in children and adolescents. PsychologicalAssessment, 23(2),311-324.

Harimukthi, T. M.,\& Dewi, S. K. (2014). Eksplorasi kesejahteraan psikologis individu dewasa awal penyandang tunanetra. Jurnal Psikologi Undip, 13(1), 64-77.

Kumar, V. G. 2008. Psychological stress and coping strategies of the parents of mentally challenged children. Journal of the Indian Academy of Applied Psychology, 34(2), 227-231.

Park, N., Peterson, C., \& Seligman, M. E. P. 2004. Strengths of character and wellbeing. Journal of Social and Clinical Psychology, 23(5), 603-619.

Ryff, C.D. 1989. Happiness is everything, or is it? explorations on the meaning of psychological well-being. Journal of Personality and Social Psychology, 57, 1069-1081.

dan Keyes, C. L. M. 1995. The structure of psychological well-being revisited. Journal of Personality and Social Psychology, 69, 719-727.

Sugiyono. 2011. Metode penelitian kuantitatif, kualitatif dan $r \& d$. Bandung: Alfabeta.

Suharmini, T. 2009. Psikologi Anak Berkebutuhan Khusus. Yogyakarta: Kanwa Publisher.

Watkins, P. C., Woodward, K., Stone, T., \& Kolts, R. L. 2003. Gratitude and happiness: development of ameasure of gratitude, and relationship with subjective well-being. Social Behavior and Personality: An International Journal, 31(5), 431-452.

Wood, A. M., Joseph, S., \& Maltby, J. 2009. Gratitude predicts psychological wellbeing above the big five facets. Personality and Individual Differences, 46, 443-447. 
. Maltby, J., Gillett, R., Linley, P. A., \& Joseph, S. 2008. The role of gratitude in the development of social support, stress, and depressiom: two longitudinal studies. Journal of Research in Persinality, 854871.
Ziskis, A. S. 2010. The relationship between personality, gratitude, dan psychological well-being. Disertasi. New Jersey Graduate School - New Brunswick Rutgers. 